\title{
In vitro fermentability and prebiotic potential of soyabean Okara by human faecal microbiota
}

\author{
E. Pérez-López ${ }^{1}$, D. Cela ${ }^{2}$, A. Costabile ${ }^{2,3}$, I. Mateos-Aparicio ${ }^{4 *}$ and P. Rupérez ${ }^{1 *}$ \\ ${ }^{1}$ Metabolism and Nutrition Department, Instituto de Ciencia y Tecnología de Alimentos y Nutrición (ICTAN), Consejo Superior \\ de Investigaciones Científicas (CSIC), José Antonio Novais 10, Ciudad Universitaria, E-28040 Madrid, Spain \\ ${ }^{2}$ Food \& Nutritional Sciences Unit, School of Chemistry, Food and Pharmacy, University of Reading, Reading, UK \\ ${ }^{3}$ Life Sciences Department, Health Sciences Research Centre, Whitelands College, University of Roehampton, UK \\ ${ }^{4}$ Departamento de Nutrición y Bromatología II, Bromatología, Facultad de Farmacia, Universidad Complutense de Madrid, \\ Ciudad Universitaria, E-28040 Madrid, Spain
}

(Submitted 11 May 2016 - Final revision received 16 June 2016 - Accepted 27 June 2016 - First published online 29 July 2016)

\begin{abstract}
At present, there is a huge interest in finding new prebiotics from agrofood industrial waste, such as the soyabean by-product Okara, rich in insoluble dietary fibre. A previous treatment of Okara with high hydrostatic pressure assisted by the food-grade enzyme Ultraflo ${ }^{\circledR} \mathrm{L}$ achieved a $58.2 \%$ increment in its soluble dietary fibre (SDF) contents. Therefore, potential prebiotic effect of both treated and native Okara was assayed using $48 \mathrm{~h}$, pH-controlled, anaerobic batch cultures inoculated with human faecal slurries, which simulate the human gut. Changes in faecal microbiota were evaluated using $16 \mathrm{~S}$ rRNA-based fluorescence in situ hybridisation, whereas release of SCFA and lactic acid was assessed by HPLC. Both Okara samples exhibited potential prebiotic effects but Okara treated to maximise its SDF content showed higher SCFA plus lactic acid, better growth promotion of beneficial bacteria, including bifidobacteria after 4 and $48 \mathrm{~h}$ and lactobacilli after $4 \mathrm{~h}$ of fermentation, and a greater inhibition of potentially harmful bacterial groups such as clostridia and Bacteroides. Differences found between fructo-oligosaccharides and Okara substrates could be attributed to the great complexity of Okara's cell wall, which would need longer times to be fermented than other easily digested molecules, thus allowing an extended potential prebiotic effect. These results support an in vitro potential prebiotic effect of Okara.
\end{abstract}

Key words: Okara: Hydrostatic pressure: Ultraflo ${ }^{\circledR}$ L enzyme: Fermentation: Microbiota: Prebiotics: Food by-products

It is generally accepted that non-digestible dietary carbohydrates resistant to digestion in the small intestine - are the main substrates available for fermentation by bacteria in the human colon $^{(1)}$. When this fermentation is carried out by selective bacteria, causing a beneficial effect on the gut microbiota and consequently on the host, they are considered prebiotics ${ }^{(2-4)}$. Many of the beneficial health effects are related to soluble dietary fibre (SDF) and non-digestible oligosaccharides, such as the regulation of metabolic disorders related to obesity and reduction of cancer risk ${ }^{(2,3,5)}$. The most important healthpromoting bacteria of the gut microbiota are bifidobacteria and lactobacilli. Both are common targets for dietary intervention that improves health ${ }^{(1,6-8)}$. Other bacteria such as streptococci, enterococci, eubacteria and Bacteroides can be classified as potentially beneficial to health or as potentially harmful depending on the species ${ }^{(7)}$. Healthy bacteria are beneficial to the host through their metabolisms such as SCFA formation (principally acetate, propionate and butyrate), absence of toxin production and synthesis of defensins or vitamins ${ }^{(9-11)}$.

Typical prebiotics include SDF, inulin-derived fructans (fructo-oligosaccharides; FOS) and galacto-oligosaccharides (GOS) $)^{(3,7,9,12)}$, but nowadays there is great interest in finding novel prebiotics from waste biomass or by-products from food industry ${ }^{(9,13-15)}$. New candidates for prebiotics include polydextrose, lactosucrose, malto-oligosaccharides, gluco-oligosaccharides, xylo-oligosaccharides and soyabean oligosaccharides $^{(1,3,4,16)}$. One of these promising potential prebiotics is Okara, an abundant and inexpensive by-product obtained after extraction of the soluble fraction from soyabean seed for tofu or soyamilk production ${ }^{(17-20)}$, and its re-valorisation would be economically valuable. Okara is an insoluble by-product and has a more complete nutritional profile than current prebiotics in the market (inulin, FOS, GOS) as it contains not only dietary fibre but also protein, oil and

Abbreviations: DNS; dinitrosalicylic acid method; FOS, fructo-oligosaccharides; HHP, high hydrostatic pressure; IDF; insoluble dietary fibre; SDF, soluble dietary fibre.

* Corresponding authors: I. Mateos-Aparicio, email inmateos@ucm.es; P. Rupérez, email pruperez@ictan.csic.es 
minerals. Okara has a high total dietary fibre (TDF) content of 54-55\% (50-51\% insoluble dietary fibre (IDF) and $4.5 \%$ SDF) and 3.9 (SD 0.2)\% of low molecular weight (MW) carbohydrates (LMWC) (0.4 (SD 0.1)\% inulin, 1.4 (SD 0.1)\% stachyose + raffinose, $0 \cdot 2(\mathrm{sD} \leq 0 \cdot 1) \%$ glucose $^{(17,20-23)}$. Okara has been proven to be a potential weight-loss supplement, with potential prebiotic effect because of its high TDF content and beneficial effects on lipid metabolism $^{(18-20,24,25)}$

The traditional treatment of plant polysaccharides to obtain prebiotic oligosaccharides is with enzymes, but recently there is an increasing interest in the use of new technologies such as autohydrolysis with elevated temperature and pressure applied to by-products ${ }^{(9,13,26)}$. Furthermore, new technologies have been applied to soyabean and even to Okara. For example, high-pressure microfluidisation and fermentation by Lactobacillus delbrueckii subsp. bulgaricus of soyabean waste produce an increase in SDF by degradation of insoluble polymers into simple carbohydrates ${ }^{(27)}$. Moreover, high hydrostatic pressure (HHP) has been previously used for SDF maximisation in Okara $^{(21,22,28)}$, with the advantage that it does not affect organoleptic attributes and can extend the shelf-life of products ${ }^{(29-31)}$. In addition, the use of enzymes to increase SDF content in food products has been reported, including soyabean ${ }^{(32-35)}$. A foodgrade enzyme (Ultraflo ${ }^{\circledR} \mathrm{L}$; Novozymes) has been used to digest Okara at atmospheric pressure ${ }^{(23,36)}$ and the combined effects of both, HHP and Ultraflo ${ }^{\circledR}$ L, have been successfully applied to maximise the SDF content of Okara by our group ${ }^{(28)}$.

Evaluation of potential prebiotics includes different approaches. First, the capacity of certain beneficial bacteria to grow in culture media containing the selected ingredient has to be verified $^{(3,4)}$. This effect as well as its non-digestible nature have been proven in native and enzymatically treated Okara ${ }^{(20,23)}$. Next, the potential prebiotic ingredient could be fermented in vitro, before an in vivo animal experiment followed by human trials $^{(3,4)}$. Native Okara has demonstrated a beneficial effect on lipid profiles of plasma in Syrian hamsters ${ }^{(24)}$, as well as a potential weight loss and prebiotic effect in Wistar rats ${ }^{(19,25)}$. However, as far as we know, a fermentative colonic model has not been used to demonstrate the prebiotic effect of Okara.

Therefore, the present study aimed to evaluate - using in vitro batch culture systems modelling the human gut - the potential prebiotic properties of native Okara and after its treatment for SDF maximisation via HHP assisted by a food-grade enzyme.

\section{Methods}

\section{Substrate}

Fresh Okara, obtained as an industrial by-product from soyabean (Glycine max (L.) Merr), was provided by Toofu-Ya S.L., a local food processing company (Arganda del Rey). At the laboratory, fresh Okara was freeze-dried (Virtis Bench Top 3L; Hucoa-Erlöss S.A.), then defatted by extraction with ethylic diethyl ether in a Soxtec System (Tecator) and kept in airtight containers at room temperature until use. Before enzymatic or HHP treatment, Okara was re-hydrated in water $(15 \%, \mathrm{w} / \mathrm{v})$ with constant shaking in a Heidolph Reax 2 rotatory shaker (Heidolph Instruments $\mathrm{GmbH} \& \mathrm{Co}$. KG) overnight.
All solutions, including dilutions and mobile phases for HPLC, were prepared with ultrapure water.

High hydrostatic pressure treatment assisted by Ultraflo ${ }^{\circledR} \mathrm{L}$ applied to Okara

Pre-hydrated Okara solution, 15\% (w/v), was treated simultaneously with Ultraflo ${ }^{\circledR}$ L (concentration of $0.025 \%$ ), a food-grade $\beta$-glucanase (endo- $\beta$-1,3(4)-), with both cellulase and xylanase activities (Novozymes), under HHP (pressure of $600 \mathrm{MPa}$ ) at $40^{\circ} \mathrm{C}$ for $30 \mathrm{~min}$, not considering the pressure build up and release time. These conditions were previously optimised ${ }^{(28)}$.

The treatment was performed in vacuum-sealed plastic bags (Doypack, $110 \times 200 \times 35-\mathrm{mm}$ size, $75-\mu \mathrm{m}$-thick film, Polyskin XL; Amcor Flexible Hispania) in Stansted SFP 7100:9/2C HHP equipment (Stansted Fluid Power Ltd), using water as the pressure-transmitting medium. After $\mathrm{HHP}+$ Ultraflo $^{\circledR} \mathrm{L}$ treatment, samples were stored at $-20^{\circ} \mathrm{C}$ and then freeze-dried.

Dietary fibre analysis of Okara treated with high hydrostatic pressure and assisted by Ultraflo ${ }^{\circledR} L$

After HHP and Ultraflo ${ }^{\circledR}$ L treatment, SDF and IDF in untreated control and HHP + Ultraflo ${ }^{\circledR}$ L-treated samples were determined according to the Association of Official Analytical Chemists ${ }^{(37)}$ enzymatic-gravimetric method with dialysis (12 kDa MW cut-off) ${ }^{(21,38)}$. In the SDF fraction, uronic acids (UA) were spectrophotometrically quantified by the method of $\mathrm{Scott}^{(39)}$, with galacturonic acid as the standard and neutral sugars (NS) by the anthrone method ${ }^{(40)}$ with glucose as the standard. Moreover, SDF and IDF were hydrolysed with $\mathrm{H}_{2} \mathrm{SO}_{4}(1 \mathrm{M})$ at $105^{\circ} \mathrm{C}$ for $1.5 \mathrm{~h}$, and reducing sugars were spectrophotometrically measured by the dinitrosalicylic acid method (DNS) ${ }^{(41)}$. Every spectrophotometric method was conveniently adapted for microplate reading, and the absorbance was read on a Biotek PowerWawe XS spectrophotometer (BioTek Instruments, Inc.). Thus, SDF was calculated either as reducing sugars (DNS method) or as UA + NS (from UA and anthrone methods). IDF was calculated as reducing sugars (DNS) and TDF was calculated as SDF plus IDF.

\section{Batch culture fermentations}

Batch culture fermentation vessels (100-ml working volume), previously sterilised, were filled with $45 \mathrm{ml}$ of sterile complex colonic model growth medium. The composition of this medium included, among others, peptone water $(5 \mathrm{~g} / \mathrm{l})$, yeast extract $(4.5 \mathrm{~g} / \mathrm{l}), \operatorname{starch}(5 \mathrm{~g} / \mathrm{l})$, tryptone $(5 \mathrm{~g} / \mathrm{l}), \mathrm{NaCl}(4.5 \mathrm{~g} / \mathrm{l})$, $\mathrm{KCl}(4.5 \mathrm{~g} / \mathrm{l})$, mucin $(4 \mathrm{~g} / \mathrm{l})$, casein $(3 \mathrm{~g} / \mathrm{l})$, pectin $(2 \mathrm{~g} / \mathrm{l})$, xylan $(2 \mathrm{~g} / 1)$, arabinogalactan $(2 \mathrm{~g} / 1)$ and inulin $(1 \mathrm{~g} / 1)^{(42,43)}$, trying to simulate a common and complex human diet. All media and chemicals were purchased from Oxoid and Sigma. Subsequently, the vessels were connected to a circulating water bath at $37^{\circ} \mathrm{C}$ and sparged with $\mathrm{O}_{2}$-free $\mathrm{N}_{2}$ gas overnight to create anaerobic conditions before inoculation. The $\mathrm{pH}$ was adjusted between 6.7 and 6.9 using $\mathrm{pH}$ meter controllers with $\mathrm{NaOH}$ or $\mathrm{HCl}$ (Electrolab260; Electrolab Ltd), and then $5 \mathrm{ml}$ of faecal slurry, prepared as $10 \% \mathrm{w} / \mathrm{v}$ in $0 \cdot 1 \mathrm{~m}$ sterile PBS ( $\mathrm{pH} 7)$, was inoculated into each vessel. Three different experiments, 
with different healthy human donors, were completed. The volunteers were free of any known metabolic and gastrointestinal diseases, were not taking probiotic or prebiotic supplements and had not taken antibiotics for 6 months before faecal sample donation. Verbal informed consent was obtained from all donors, according to the ethical guidelines of the University of Reading. In total, four vessels were used, in triplicate (four vessels per donor), with either $0.5 \mathrm{~g}$ of freezedried HHP + Ultraflo $^{\circledR}$ L Okara or native Okara samples, $0.5 \mathrm{~g}$ of FOS (Orafti ${ }^{\circledR}$ P95; BENEO $\mathrm{GmbH}$ ) as a positive control and another vessel without any sample (negative control). Predigestion of Okara was not needed according to our previous studies $^{(20)}$. Batch cultures were run for $48 \mathrm{~h}$, and 5-ml aliquots were taken at times $0,4,8,24$ and $48 \mathrm{~h}$ for analysing bacterial populations by fluorescent in situ hybridisation (FISH) and for SCFA and lactic acid analyses by HPLC.

\section{Enumeration of bacterial populations by fluorescence in situ hybridisation analysis}

The bacterial groups Chis 150 - Clostridium histolyticum $^{(44)}$, Lab 158 - lactobacilli ${ }^{(45)}$, Erec 482 - Clostridium coccoides and Eubacterium rectale ${ }^{(44)}$, Prop 853 - Clostridial cluster $\mathrm{IX}^{(46)}$, Rfla 729-Rbro 730 - Ruminococcus albus and Ruminococcus flavefaciens/Clostridium sporosphaeroides, Ruminococcus bromii and Clostridium leptum ${ }^{(47)}$, Bac 303 - Bacteroides ${ }^{(48)}$, Bif 164 - Bifidobacterium ssp. ${ }^{(49)}$ and Eub 338 I-II-III-domain bacteria $^{(50)}$ were identified using synthetic oligonucleotide probes targeting specific regions of the $16 \mathrm{~S}$ ribosomal RNA molecule, labelled with the fluorescent dye Cy3.

An aliquot $(375 \mu \mathrm{l})$ from each vessel at each time point was fixed during $4 \mathrm{~h}\left(4^{\circ} \mathrm{C}\right)$ in $1125-\mu \mathrm{l}(4 \% \mathrm{w} / \mathrm{v})$ paraformaldehyde. Next, the samples were centrifuged at $13000 \boldsymbol{g}$ for $5 \mathrm{~min}$ and washed twice in $1-\mathrm{ml}$, sterilised PBS. The pellets were re-suspended in $150-\mu \mathrm{PBS}+150-\mu$ l ethanol and stored $\left(-20^{\circ} \mathrm{C}\right)$.

For hybridisation, samples were diluted in an appropriate amount of PBS/SDS for each probe. Aliquots $(20 \mu \mathrm{l})$ were applied in each well of a six-well polytetrafluoroethylene and poly-L-lysine-coated six-well slide (Tekdon Inc.). After drying for $15 \mathrm{~min}$ in a drying chamber (at 46 or $50^{\circ} \mathrm{C}$ ), the slides were sequentially dehydrated in alcohol (50, 80 and 96\% v/v, ethanol) for $3 \mathrm{~min}$ in each solution. Gram + bacterial groups needed a previous treatment with lysozyme $(20 \mu \mathrm{l})$, followed by ethanol dehydration. A 50- $\mu$ l aliquot of an appropriate hybridisation buffer and $5 \mu \mathrm{l}$ of a fluorescent-marked oligonucleotide probe were added to the slide, and incubated for $4 \mathrm{~h}$ in a microarray hybridisation incubator (Grant Boekel). Next, hybridisation slides were washed in 50-ml washing buffer, containing $20 \mu \mathrm{l}$ of 4',6-diamidino-2-phenylindole dihydrochloride $(50 \mathrm{ng} / \mu \mathrm{l}$; Sigma), for $15 \mathrm{~min}$ and dried with compressed air. The composition of the hybridisation and wash buffers depended on the rRNA probe as reported in probe Base ${ }^{(51)}$. A 5- $\mu$ l aliquot of anti-fade reagent (polyvinyl alcohol mounting medium with DABCO ${ }^{\circledR}$ antifading; Sigma) was added to each well and a coverslip was placed. Finally, the slides were counted (fifteen different fields for each sample) with an epifluorescence microscope (Eclipse 400; Nikon) using the Fluor 100 lens. The means of the three donors were expressed as $\log _{10}$ cells $/ \mathrm{ml}^{(52,53)}$.

\section{Analysis of SCFA and lactic acid}

Samples $(1 \mathrm{ml})$ from each fermentation time point were centrifuged (13000 g, $10 \mathrm{~min})$, and supernatants were filtered through $0 \cdot 2-\mu \mathrm{m}$ Acrodisc ${ }^{\circledR}$ Syringe Filters with hydrophilic polyvinylidene fluoride membrane, $13 \mathrm{~mm}$ (Pall Corporation). Aliquots $(20 \mu \mathrm{l})$ were injected into an HPLC system (Merck), equipped with a refraction index detector. The column used was an ion-exclusion REZEX-ROA organic acid column (Phenomenex Inc.), maintained at a constant temperature of $85^{\circ} \mathrm{C}$. The eluent was sulphuric acid in ultrapure water $(0.0025 \mathrm{mmol} / \mathrm{l})$, with a flow rate of $0.5 \mathrm{ml} / \mathrm{min}$. Calibration curves for lactate, acetate, propionate and butyrate (12.5-100 mm) were accomplished for SCFA quantification. The mean metabolite concentrations were expressed as $\mathrm{mm}^{(43)}$.

\section{Statistical analysis}

Results were expressed as means and standard deviations. At least, three different measurements were accomplished for each mean. Comparison of dietary fibre means was performed by one-way ANOVA with a significance level of $P<0.05$. Statgraphic version 5.1 was used. Bacterial counts by FISH and SCFA and lactic acid data were analysed by 2 -way ANOVA with Bonferroni post-tests with $P<0.05$. In addition, a paired $t$ test was applied in order to assess the significance of the results of single pairs of data using GraphPad Prism 5.0 (GraphPad Software).

\section{Results}

\section{Dietary fibre analysis}

In order to obtain a SDF-enriched product, HHP treatment assisted by Ultraflo ${ }^{\circledR} \mathrm{L}$ was applied to Okara, and the dietary fibre content was determined according to the $\mathrm{AOAC}^{(37)}$ enzymatic-gravimetric method with dialysis (12 kDa MW cut-off) $^{(21,38)}$.

Dietary fibre contents in native Okara and after treatment with HHP assisted by enzymes are shown in Table 1. An overall increase in SDF was reported when Okara was treated with HHP and Ultraflo ${ }^{\circledR}$ L. When SDF was expressed as the sum of UA and NS, a SDF value that was 1.58-fold higher was reported.

Table 1. Dietary fibre in native Okara and after treatment with high hydrostatic pressure assisted by Ultraflo ${ }^{\circledR} \mathrm{L}$ (Mean values and standard deviations, $n 3$ )

\begin{tabular}{|c|c|c|c|c|c|}
\hline \multirow[b]{2}{*}{ Analytical methods } & \multirow[b]{2}{*}{ Dietary fibre } & \multicolumn{2}{|c|}{$\begin{array}{l}\text { Native Okara } \\
\text { (\% d.w.) }\end{array}$} & \multicolumn{2}{|c|}{$\begin{array}{c}\text { Treated Okara } \\
(\% \text { d.w. })\end{array}$} \\
\hline & & Mean & SD & Mean & SD \\
\hline $\mathrm{NS}+\mathrm{UA}$ & SDF & $2 \cdot 20^{\mathrm{a}}$ & 0.09 & $3.48^{b}$ & 0.01 \\
\hline \multirow[t]{3}{*}{ DNS } & SDF & $0.37^{a}$ & 0.15 & $2 \cdot 34^{b}$ & $<0.01$ \\
\hline & IDF & $36.94^{b}$ & 0.76 & $22 \cdot 16^{\mathrm{a}}$ & 0.07 \\
\hline & TDF & $37 \cdot 31^{b}$ & 0.77 & $24.50^{\mathrm{a}}$ & 0.07 \\
\hline
\end{tabular}

d.w., dry weight; NS, neutral sugars; UA, uronic acid; DNS, 3,5-dinitrosalicylic acid; SDF, soluble dietary fibre; IDF, insoluble dietary fibre; TDF, total dietary fibre.

a,b Mean values within a row with unlike superscript letters were significantly different $(P<0.05)$. 
However, low SDF content was reported in native Okara when reducing sugars were measured by the DNS method (6.32-fold higher with the treatment). IDF and TDF showed a 0.60and 0.66-times reduction, respectively, when the treatment was applied.

\section{Enumeration of bacterial populations by fluorescence in situ hybridisation analysis}

The potential prebiotic effect of native Okara and HHP assisted by Ultraflo ${ }^{\circledR}$ L-treated Okara on the main bacterial groups constituting the human intestinal microbiota were assessed by FISH analysis. Specific microbiota groups such as lactic acid bacteria and butyrate producers were chosen as they are the most important bacteria, whose growth has been related to the prebiotic effect. Other bacterial groups, mainly related to dietary fibre fermentation, were also included. Potentially harmful bacterial groups were selected to monitorise a possible decrease. The analyses were performed at 0, 4, 8, 24 and $48 \mathrm{~h}$ of fermentation as reported in Fig. 1.

For total bacteria (Eub 338 I- II- III), no differences between treatments were found by two-way ANOVA with Bonferroni post-tests, but $t$ test $(P<0.05)$ showed a prolonged growing stage when HHP + Ultraflo $^{\circledR}$ L-treated Okara was added as the substrate. HHP + Ultraflo ${ }^{\circledR} \mathrm{L}$ and native Okara showed an in vitro bifidogenic activity (Bif 164) at 4 (both) and $48 \mathrm{~h}$ (only $\mathrm{HHP}+$ Ultraflo $^{\circledR} \mathrm{L}$ Okara) of fermentation $\left(4 \mathrm{~h}: \mathrm{HHP}+\right.$ Ultraflo $^{\circledR}$ L Okara, $\log _{10} / \mathrm{ml} 8.88$ (sD 0.09) and native Okara, $\log _{10} / \mathrm{ml} 8.89$ (sD 0.15), $48 \mathrm{~h}: \mathrm{HHP}+$ Ultraflo $^{\circledR} \mathrm{L}$ Okara, $\log _{10} / \mathrm{ml} 9 \cdot 34$ (sD 0.06)) (Fig. 1 and 2) compared with negative control ( $4 \mathrm{~h}: \log _{10} / \mathrm{ml}$ 8.62 (sD 0.18) and $48 \mathrm{~h}: \log _{10} / \mathrm{ml} 9.02$ (SD 0.15)). Both treated and native Okara exhibited a significant increase in bifidobacteria up to $8 \mathrm{~h}$ ( $t$ test, $P<0.05)$.

For lactobacillus/enterococcus spp., an increase at $4 \mathrm{~h}$ was noticed for treated and native Okara with two-way ANOVA $\left(\log _{10} / \mathrm{ml} 8.73\right.$ (SD 0.08) and $\log _{10} / \mathrm{ml} 8.72$ (SD 0.03) respectively),
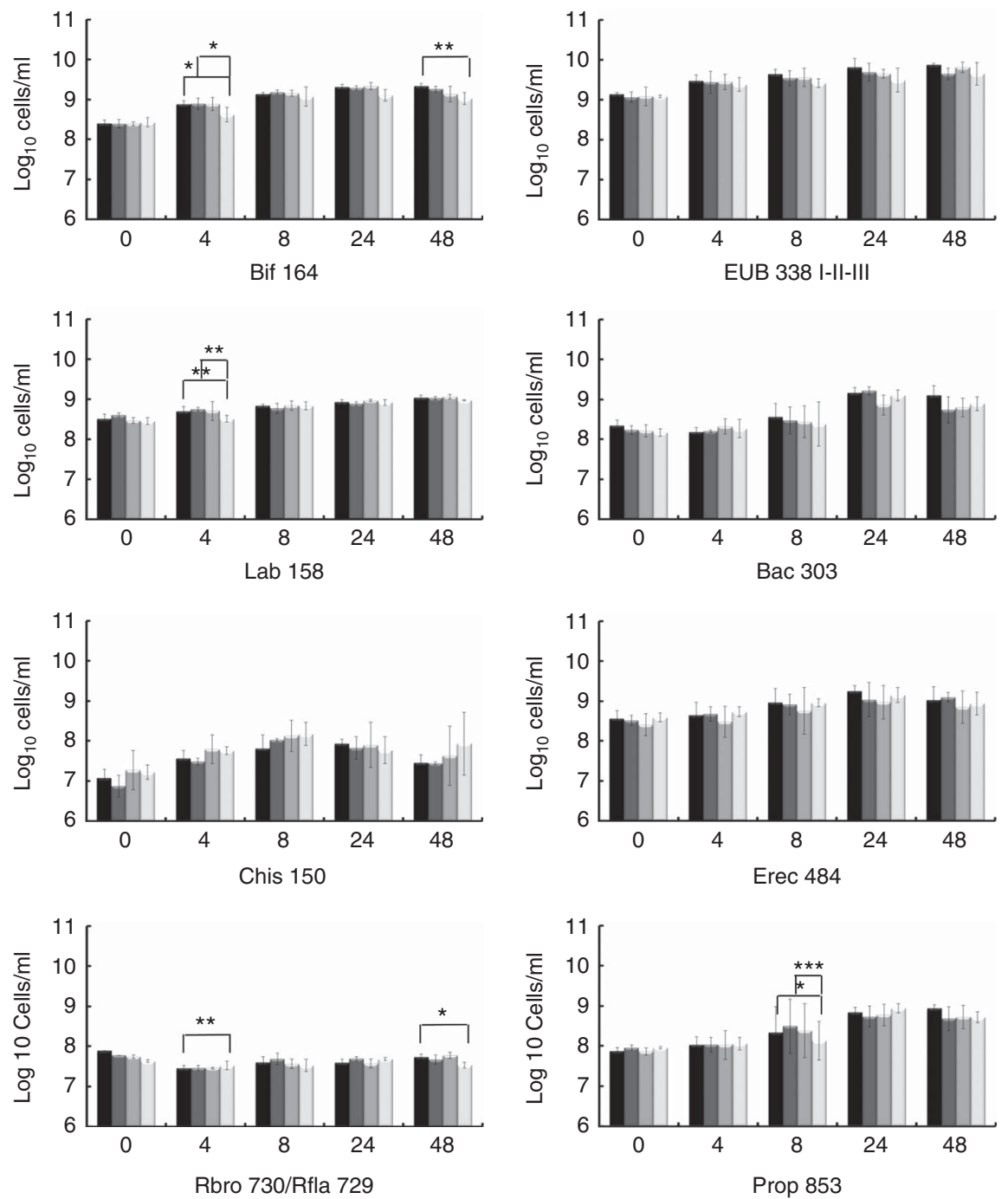

Fig. 1. Fluorescence in situ hybridisation analysis (FISH) of bacterial population in $\mathrm{pH}$-controlled faecal batch cultures on Okara treated with high hydrostatic pressure (HHP) and assisted by Ultraflo ${ }^{\circledR} \mathrm{L}(\square)$, native Okara $(\square)$, FOS $(\square)$ and negative control $(\square)$ as substrates. FOS (Orafti ${ }^{\circledR}$ P95): fructo-oligosaccharides. Results are mean values of triplicate analyses and are expressed as $\log _{10}$ cells $/ \mathrm{ml}$, and standard deviations. ${ }^{*} P<0.05,{ }^{* *} P<0.01,{ }^{* * *} P<0.001$ are significantly different. 
(a)

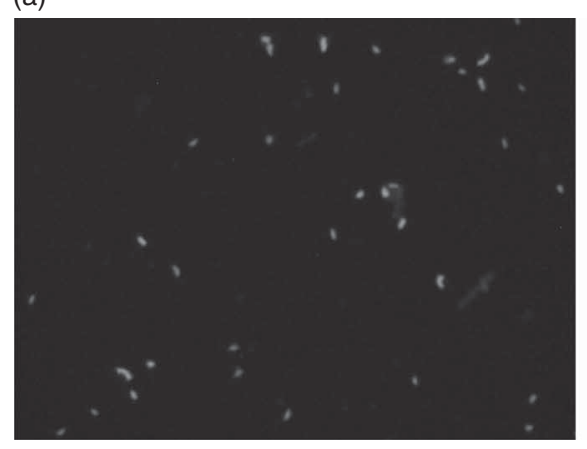

(b)

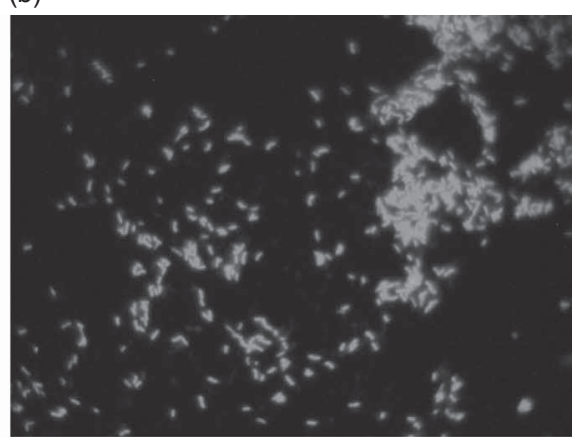

Fig. 2. Fluorescence in situ hybridisation (FISH) analysis of Bifidobacterium in batch culture at $48 \mathrm{~h}$ growing on (a) negative control, and (b) Okara treated with HHP and assisted by Ultraflo ${ }^{\circledR} \mathrm{L}$. ${ }^{\star \star} P<0.001$, significantly different.

compared with negative control $\left(\log _{10} / \mathrm{ml} 8.51\right.$ (SD 0.08)). With $\mathrm{HHP}+$ Ultraflo $^{\circledR}$ L-treated Okara, lactobacilli grew constantly, whereas with native Okara the growth was mainly found between 4 and $24 \mathrm{~h}$.

No statistical differences between treatments were found for Bacteroides spp. (Bac 303), C. coccoides and E. rectale group (Erec 482) and the C. bistolyticum group (Chis 150). However, Bacteroides spp. significantly increased after $24 \mathrm{~h}$ of incubation, whereas treated Okara promoted a lower growth rate at $24 \mathrm{~h}$ $\left(\mathrm{HHP}+\right.$ Ultraflo $^{\circledR} \mathrm{L}$ Okara, $\log _{10} / \mathrm{ml} 9 \cdot 16$ (SD 0.13) and native Okara, $\log _{10} / \mathrm{ml} 9 \cdot 22$ (SD 0.10)). An increase in Erec 482 was noticed after $8 \mathrm{~h}$ of incubation when treated Okara or when native Okara was added in both cases ( $t$ test, $P<0.05$ ). Numbers of clostridia only increased in the first $4 \mathrm{~h}$ of incubation and decreased after $24 \mathrm{~h}$. Moreover, treated Okara had a smaller Chis 150 population than native Okara, and both were lesser than FOS and negative control. Rfla 729-Rbro 730 (R. albus and $R$. flavefaciens - C. sporosphaeroides, R. bromii and C. leptum) revealed a low growth rate, with statistical differences between treated Okara and negative control at $4 \mathrm{~h}$ (the negative control was higher) and $48 \mathrm{~h}\left(\mathrm{HHP}+\right.$ Ultraflo $^{\circledR} \mathrm{L}: \log _{10} / \mathrm{ml} 7.73$ (SD 0.08), and negative control: $\log _{10} / \mathrm{ml} 7.53$ (sD 0.07)) (Fig. 1). Differences in Clostridial cluster IX (Prop 853) between Okara treated with HHP and assisted by Ultraflo ${ }^{\circledR} \mathrm{L}$, native Okara and negative control were appreciated at $8 \mathrm{~h}\left(\mathrm{HHP}+\right.$ Ultraflo $^{\circledR} \mathrm{L}: \log _{10} / \mathrm{ml}$ 8.69 (SD 0.21), Okara: $\log _{10} / \mathrm{ml} 8.88$ (SD 0.14) and negative control: $\log _{10} / \mathrm{ml} 8 \cdot 12$ (sD 0.49)). Remarkable differences in growth kinetics among all treatments and negative control could be appreciated for Prop 853, as the increase in bacteria was first appreciated at $8 \mathrm{~h}$ for every treatment except for negative control, which started at $24 \mathrm{~h}$.

\section{Analysis of SCFA and lactic acid}

Differences between both native and HHP + Ultraflo $^{\circledR}$ L-treated Okara and negative control $(P<0.05)$ and FOS $(P<0.01)$ were appreciated in the production of acetic acid after $24 \mathrm{~h}$ of fermentation, whereas changes in propionic acid production were revealed at 8 and $48 \mathrm{~h}(P<0.001)$ (Table 2$)$. When comparing total increase in organic acids, HHP + Ultraflo $^{\circledR}$ L-treated Okara produced 1.12- and 1.36-fold higher acetic acid and propionic acid, respectively, compared with native Okara. No differences in butyric acid production between treatments were appreciated. An increase was only noticed ( $t$ test $P<0 \cdot 05$ ) in HHP assisted by Ultraflo ${ }^{\circledR}$ L-treated Okara after $24 \mathrm{~h}$ of fermentation. Nevertheless, butyric acid production was $2 \cdot 68$-fold higher after $48 \mathrm{~h}$ of fermentation, and 1.55-fold higher when $\mathrm{HHP}+$ Ultraflo $^{\circledR}$ L-treated Okara was added instead of native Okara. Lactic acid presented differences among treatments at $4 \mathrm{~h}$ (native Okara was 2.45- and 2.60-fold higher than FOS and negative control, respectively). After $8 \mathrm{~h}$, lactic acid was not detected. Considerable differences between donors were found for all organic acids. No significant levels of branched-chain fatty acids from the fermentation of resistant protein were found ${ }^{(54)}$.

\section{Discussion}

According to our present results, a potential prebiotic effect of native Okara and HHP + Ultraflo ${ }^{\circledR}$ L-treated Okara has been found, with capacity to promote the growth of beneficial bacteria, including bifidobacteria after 4 and $48 \mathrm{~h}$ (Fig. 2) and of lactobacilli after $4 \mathrm{~h}$ of in vitro faecal batch culture fermentation simulating the human gut. Previous digestion of Okara was not necessary as it is indigestible ${ }^{(20)}$.

Results obtained from the in vitro batch culture systems suggest that potential prebiotic effect is shown by Okara of soyabean, particularly after $\mathrm{HHP}$ treatment $\left(600 \mathrm{MPa}, 40^{\circ} \mathrm{C}, 30 \mathrm{~min}\right)$ assisted by Ultraflo ${ }^{\circledR} \mathrm{L}(0.025 \%)$, which needs further research to assess the effect in vivo. In fact, differences between samples were noticed, as a bifidogenic effect of treated Okara after 4 and $48 \mathrm{~h}$ of batch culture (Fig. 2), whereas native Okara did not bring about such effects at $48 \mathrm{~h}$ (Fig. 1). Moreover, even if there were no statistical differences at $8 \mathrm{~h}$ in lactobacilli, $\mathrm{HHP}+$ Ultraflo $^{\circledR}$ L-treated Okara performed better, whereas at $4 \mathrm{~h}$ differences with the negative control were observed in both Okara samples. Other potentially beneficial bacteria such as the Ruminococcus group showed an increase in HHP + Ultraflo $^{\circledR}$ L Okara at $48 \mathrm{~h}$. SCFA values also suggested a better potential prebiotic response when treated Okara was fermented, especially in acetic acid ( $48 \mathrm{~h}$ ) and butyrate (24-48 h) contents (Table 2).

The prebiotic effect of soyabean oligosaccharides has been previously suggested. For example, raffinose and stachyose have been found to be growth promoters of Bifidobacterium infantis ${ }^{(7)}$. Moreover, Okara can be fermented by Streptococcus thermophilus 
Table 2. SCFA and lactic acid contents of batch cultures with Okara treated with high hydrostatic pressure and assisted by Ultraflo ${ }^{\circledR}$ L, native Okara, fructo-oligosaccharides (FOS) and a negative control (Mean values and standard deviations, $n$ )

\begin{tabular}{|c|c|c|c|c|c|c|c|c|c|}
\hline \multirow[b]{3}{*}{ SCFA } & \multirow[b]{3}{*}{ Time (h) } & \multicolumn{8}{|c|}{ Substrate } \\
\hline & & \multicolumn{2}{|c|}{ Treated Okara } & \multicolumn{2}{|c|}{ Native Okara } & \multicolumn{2}{|c|}{ FOS } & \multicolumn{2}{|c|}{ Negative control } \\
\hline & & Mean & SD & Mean & SD & Mean & SD & Mean & SD \\
\hline \multirow[t]{5}{*}{ Acetic acid } & 0 & 68.21 & 13.59 & 48.77 & 21.85 & 37.02 & 1.59 & 40.42 & 21.55 \\
\hline & 4 & 52.88 & 29.53 & 56.71 & 9.85 & 36.65 & $12 \cdot 73$ & 47.95 & 1.00 \\
\hline & 8 & $142 \cdot 48$ & 19.98 & 155.63 & $72 \cdot 28$ & $122 \cdot 88$ & 30.69 & $107 \cdot 19$ & $72 \cdot 19$ \\
\hline & 24 & $229 \cdot 14^{*}+\dagger$ & 78.38 & $312 \cdot 39^{*}+\dagger$ & 77.94 & $165 \cdot 73$ & 51.94 & 208.09 & 73.53 \\
\hline & 48 & 244.97 & 21.09 & $206 \cdot 36$ & $62 \cdot 30$ & 238.92 & $17 \cdot 33$ & 214.35 & $50 \cdot 89$ \\
\hline \multirow[t]{5}{*}{ Propionic acid } & 0 & 8.87 & 1.00 & 39.15 & 9.27 & $14 \cdot 28$ & 19.29 & 3.47 & 1.69 \\
\hline & 4 & 3.33 & 1.38 & $45 \cdot 38$ & 2.82 & 3.49 & 2.82 & 15.49 & $22 \cdot 77$ \\
\hline & 8 & $131 \cdot 37^{\star \star \star}+\dagger \dagger$ & 5.64 & $162 \cdot 88^{\star \star \star}+\dagger \dagger$ & 44.91 & $15 \cdot 52$ & $3 \cdot 21$ & $2 \cdot 28$ & $1 \cdot 31$ \\
\hline & 24 & 68.31 & 5.08 & $87 \cdot 12$ & $22 \cdot 12$ & $64 \cdot 31$ & 5.43 & 58.52 & $36 \cdot 72$ \\
\hline & 48 & $178 \cdot 31^{\star \star \star}+† \dagger$ & 116.05 & $163.61^{\star \star \star}+\dagger \dagger$ & 21.87 & 47.34 & 1.00 & 51.00 & 1.00 \\
\hline \multirow[t]{5}{*}{ Butyric acid } & 0 & 14.88 & 5.59 & 10.92 & 2.69 & $10 \cdot 33$ & 5.03 & 7.44 & $5 \cdot 11$ \\
\hline & 4 & 9.58 & 5.51 & 9.92 & 5.73 & 12.95 & 4.45 & $9 \cdot 27$ & 4.45 \\
\hline & 8 & 11.1 & 1.23 & $17 \cdot 16$ & 4.90 & 13.63 & 0.88 & $13 \cdot 18$ & 0.87 \\
\hline & 24 & 29.58 & 14.83 & $27 \cdot 25$ & 17.35 & 18.90 & 10.98 & 22.55 & $10 \cdot 32$ \\
\hline & 48 & 39.87 & 8.39 & 27.00 & 8.68 & $32 \cdot 12$ & $12 \cdot 73$ & $25 \cdot 30$ & $6 \cdot 60$ \\
\hline \multirow[t]{5}{*}{ Lactic acid } & 0 & 10.91 & 1.49 & 8.56 & 7.89 & 6.09 & 1.57 & $6 \cdot 19$ & 3.39 \\
\hline & 4 & 26.52 & 3.38 & $41.08^{\star \star \star}+\dagger \dagger$ & $16 \cdot 97$ & $16 \cdot 77$ & 6.64 & $15 \cdot 79$ & 7.97 \\
\hline & 8 & $26.75+1 \dagger$ & 3.89 & $18 \cdot 87^{\star \star \star}+\dagger \dagger$ & 6.42 & $53 \cdot 1$ & $12 \cdot 36$ & 43.38 & $10 \cdot 66$ \\
\hline & 24 & \multirow{2}{*}{\multicolumn{2}{|c|}{$\begin{array}{l}\text { ND } \\
\text { ND }\end{array}$}} & \multirow{2}{*}{\multicolumn{2}{|c|}{$\begin{array}{l}\text { ND } \\
\text { ND }\end{array}$}} & \multirow{2}{*}{\multicolumn{2}{|c|}{$\begin{array}{l}\text { ND } \\
\text { ND }\end{array}$}} & \multirow{2}{*}{\multicolumn{2}{|c|}{$\begin{array}{l}\text { ND } \\
\text { ND }\end{array}$}} \\
\hline & 48 & & & & & & & & \\
\hline
\end{tabular}

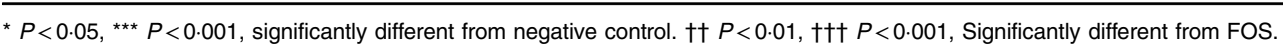


and L. delbrueckii subsp. bulgaricus ${ }^{(27)}$ and in vitro fermentation by Bifidobacterium bifidum and Lactobacillus acidophilus of native Okara or Okara treated by Ultraflo ${ }^{\circledR} \mathrm{L}$ showed positive results after 48,72 and $96 \mathrm{~h}$ of incubation, with a significant production of acetic, followed by propionic and butyric acids $(93: 5: 2 \text { at } 96 \mathrm{~h})^{(20,23)}$. In our batch culture experiments (Table 2), acetic acid was also predominant, followed narrowly by propionic acid, with a ratio of 13:12:1 after $8 \mathrm{~h}$ of incubation with HHP + Ultraflo ${ }^{\circledR}$ L Okara and 18:19:2 with native Okara, respectively. These SCFA are a source of energy for the colonic mucosa, stimulate cell proliferation, reduce cholesterol levels and have anti-proliferative effects in colorectal cancer as well as beneficial effect within the muscles, kidneys, brain and heart ${ }^{(10-12)}$. In our study, however, acetic and propionic acid levels showed differences between treatments (Table 2), only butyrate increased with time. E. rectale is one of the main producers of butyrate in the colon ${ }^{(55)}$, and no statistically significant differences have been detected in FISH (Erec 484) (Fig. 1). On the other hand, the Ruminococcus group (Rfla 729-Rbro 730) also produces butyrate ${ }^{(56)}$, and HHP + Ultraflo ${ }^{\circledR}$ L-treated Okara was significantly higher than native Okara at $48 \mathrm{~h}$ (Fig. 1), despite the low growth rate, which was also found previously by Walker et al. ${ }^{(46)}$. This could explain the reason why HHP + Ultraflo ${ }^{\circledR}$ L-treated Okara fermentation showed a tendency to increase butyrate production (Table 2), which is the preferred energy source for colonic epithelial cells and promotes normal cell differentiation and proliferation ${ }^{(12)}$. Bifidobacteria are acetate producers, and acetate increase according to their behaviour has been noticed. Furthermore, the main producer of propionic acid has been reported to be Clostridial cluster IX (Prop 853) ${ }^{(46)}$. At $8 \mathrm{~h}$ of incubation, both propionic acid levels and Clostridial cluster IX population were higher in native Okara than HHP + Ultraflo ${ }^{\circledR}$ L-treated Okara groups. Moreover, differences in SCFA production between FOS and Okara substrates could be observed, especially in propionic acid at $48 \mathrm{~h}$ (Table 2 ). This could be explained by the great complexity of Okara's cell wall ${ }^{(23,36,57)}$, which needs longer time to be fermented, allowing a longer growth rate, than other easily digested molecules such as FOS. Lactic acid, produced by lactic acid bacteria including lactobacilli, bifidobacteria, enterococci and streptococci, increased during the first few hours of fermentation, and then it was no longer detected, probably because of its utilisation by other bacteria. In fact, the production of butyric acid from lactic acid has been previously suggested $^{(58)}$, and agree with our results (Table 2 ). The results also show that some potential pathogenic bacteria could be inhibited when Okara is fermented. In fact, the $C$. bistolyticum group (Chis 150) exhibited a decrease after $24 \mathrm{~h}$ of incubation. Other potentially harmful bacteria such as the BacteroidesPrevotella group (Bac 303) also showed a decrease after $24 \mathrm{~h}$ of incubation and a lower rate at $24 \mathrm{~h}$ when $\mathrm{HHP}+$ Ultraflo $^{\circledR}$ L-treated Okara was added instead native Okara. Total bacterial levels remained unchanged among treatments, but with an increase in time, and thus variations appear to be inter-population only, as it has been previously appreciated in artichokes ${ }^{(59)}$.

The potential prebiotic effect was enhanced by previous treatment of Okara to maximise its SDF content. The effectivity of HHP and enzymatic hydrolysis to increase the amount of SDF (1.58-fold higher) has been previously reported on Okara ${ }^{(28)}$. HHP has already been used for the hydrolysis of IDF residue from Okara without enzymatic assistance ${ }^{(21,22)}$. Similarly, the food-grade enzymes Ultraflo ${ }^{\circledR} \mathrm{L}$ and cellulase were used at atmospheric pressure on Okara as a substrate ${ }^{(23,35,36)}$, with similar results. In addition, LMWC have been identified after Ultraflo ${ }^{\circledR}$ L hydrolysis of polysaccharides (arabinans, galactans, arabinogalactans, xylogalactans or glucans) present in Okara, and their potential fermentability by B. bifidus and L. acidophilus has been assessed ${ }^{(20,23)}$, which agree with the results of our present study. Kasai et al. ${ }^{(36)}$ found an increase in NS after cellulase treatment of Okara. They reported the difficulty to achieve extensive digestion of Okara, as it is composed of indigestible and complex fibres, which could explain the low amount of SDF found in native Okara (Table 1) by DNS method. With this HHP assisted by Ultraflo $^{\circledR}$ L treatment, a partial hydrolysis of the indigestible fibre has been achieved $^{(28)}$, as IDF value decreased with the treatment, increasing the amount of terminal reducing sugars, measured by DNS (Table 1). Besides, according to our previous analysis, Okara contains approximately 32, 15 and 3g/100 g DM of protein, fat and ashes, respectively, before fat extraction ${ }^{(20)}$. Soluble soyabean carbohydrates released by this treatment have other potential health benefits, such as reduction of cholesterol levels ${ }^{(60,61)}$, improvement of glucose tolerance in diabetes, and anti-inflammatory and anti-carcinogenic effects on the digestive tract ${ }^{(5,7,12)}$.

All these in vitro fermentability data support the idea that Okara from soyabean has potential prebiotic effects. According to previous studies $^{(1,3,62,63)}$, soyabean-derived oligosaccharides have not presented enough evidence to be considered as prebiotics yet, but they are promising candidates. However, although in vivo studies are needed to demonstrate that HHP + Ultraflo $^{\circledR}$ L-treated Okara selectively stimulates the growth of bacterial groups in the gut that confer health benefits to the host, all these promising results from the in vitro study, in combination with previous results, support the idea that Okara from soyabean has, in fact, potential prebiotic effects, attributable to its SDF content ${ }^{(19,20,23-25)}$. The batch culture fermentation methodology was appropriate for studying the selectivity of fermentation, changes in the main groups of the microbiota and SCFA production $^{(4,7)}$. Treatment with $\mathrm{HHP}\left(600 \mathrm{MPa}, 40^{\circ} \mathrm{C}, 30 \mathrm{~min}\right)$ assisted by Ultraflo ${ }^{\circledR} \mathrm{L}(0.025 \%)$ could have enhanced the potential prebiotic effects of Okara according to our results. In addition to its prebiotic effect, Okara is interesting from a nutritional point of view as a complete and healthy by-product from soyabean. Its re-valorisation would have an economic impact and could be used for food applications in bakery and pastry industries as a substitute of cereal flours or as a gluten-free flour for snacks ${ }^{(64)}$. These are preliminary results, but further in vivo studies are needed to determine whether these potential prebiotic effects possess beneficial health-promoting effects in humans.

\section{Acknowledgements}

The authors thank Takazumi from Toofu-Ya S.L. for providing the Okara by-product and Martínez-Gutiérrez from Novozymes Spain, S.A., for providing Ultraflo ${ }^{\circledR} \mathrm{L}$. 
E. P.-L. acknowledges the predoctoral training programme of the Education, Language Policy and Culture of the Basque Government (Spain) (grant no. PRE_2013_1_682) for her work experience contract at the Department of Metabolism and Nutrition of ICTAN-CSIC in Madrid and for providing financial support during her short stay abroad at the Food \& Nutritional Sciences Unit, School of Chemistry, Food and Pharmacy, University of Reading, UK (where the batch culture experiments were performed), under the supervision of A. C.

The author contributions are as follows: E. P.-L. was the principal investigator and contributed to the study design, analysis and interpretation of the results and wrote the manuscript; D. C. contributed to data analyses; A. C. contributed to the study design, analyses and supervision; I. M.-A. and P. R. contributed to the study design and supervision.

There are no conflicts of interest to declare.

\section{References}

1. Drakoularakou A, Rastall RA \& Gibson GR (2011) Functional foods for the gut: probiotics, prebiotics and synbiotics. In Woodhead Publishing Series in Food Science, Technology Nutrition, pp. 449-470 [M Saarela, editor]. Cambridge, UK]: Woodhead Publishing Series in Food Science Technology Nutrition.

2. Charalampopoulos D \& Rastall RA (2012) Prebiotics in foods. Curr Opin Biotech 23, 187-191.

3. Corzo N, Alonso JL, Azpiroz F, et al. (2015) Prebiotics: concept, properties and beneficial effects. Nutr Hosp 31, Suppl. 1, 99-118.

4. Gibson GR, Scott KP, Rastall RA, et al. (2010) Dietary prebiotics: current status and new definition. Food Sci Tec Bull $\mathbf{7}$, $1-19$.

5. Courtois J (2009) Oligosaccharides from land plants and algae: production and applications in therapeutics and biotechnology. Curr Opin Microbiol 12, 261-273.

6. Manning TS \& Gibson GR (2004) Prebiotics. Best Pract Res Cl Ga 18, 287-298.

7. Roberfroid M, Gibson GR, Hoyles L, et al. (2010) Prebiotic effects: metabolic and health benefits. Br J Nutr $\mathbf{1 0 4}$ S1-S63.

8. Saliminen S, Ramos P \& Fonden R (1993) Substrates and Lactic Acid Bacteria, Lactic Acid Bacteria. New York: Marcel Dekker.

9. Rastall RA \& Gibson GR (2015) Recent developments in prebiotics to selectively impact beneficial microbes and promote intestinal health. Curr Opin Biotech 32, 42-46.

10. Bergman EN (1990) Energy contributions of volatile fatty-acids from the gastrointestinal-tract in various species. Physiol Rev 70, 567-590.

11. Macfarlane S \& Macfarlane GT (2003) Regulation of shortchain fatty acid production. Proc Nutr Soc 62 , 67-72.

12. Slavin J (2013) Fiber and prebiotics: mechanisms and health benefits. Nutrients 5, 1417-1435.

13. Gullon P, Gullon B, Moure A, et al. (2009) Manufacture of prebiotics from biomass sources. In Prebiotics and Probiotics Science and Technology, pp. 535-589 [D Charalampopoulos and R Rastall, editors]. New York: Springer.

14. Mateos-Aparicio I (2011) Beans by-products, potential sources for functional ingredients. In Beans: Nutrition, Consumption and Health, pp. 17 [E Popescu and I Golubev, editors]. New York: Nova Publishers Inc.

15. Mateos-Aparicio I, Redondo-Cuenca A \& Villanueva MJ (2013) Dietary fiber from the food industry by-products.
In Dietary Fiber: Sources, Properties and Their Relationship to Health, pp. 23 [I Nova Science Publishers, editor]. New York: Nova Biomedical.

16. Moura P, Barata $\mathrm{R}$, Carvalheiro $\mathrm{F}$, et al. (2007) In vitro fermentation of xylo-oligosaccharides from corn cobs autohydrolysis by Bifidobacterium and Lactobacillus strains. LWT-Food Sci Technol 40, 963-972.

17. Mateos-Aparicio I, Redondo-Cuenca A, Villanueva MJ, et al. (2010) Pea pod, broad bean pod and okara, potential sources of functional compounds. LWT-Food Sci Technol $\mathbf{4 3}$, $1467-1470$

18. Redondo-Cuenca A, Villanueva MJ \& Mateos-Aparicio I (2008) Soybean seeds and its by-product okara as sources of dietary fibre. Measurement by AOAC and Englyst methods. Food Chem 108, 1099-1105.

19. Prestamo G, Ruperez P, Espinosa-Martos I, et al. (2007) The effects of okara on rat growth, cecal fermentation, and serum lipids. Eur Food Res Technol 225, 925-928.

20. Espinosa-Martos I \& Ruperez P (2009) Indigestible fraction of okara from soybean: composition, physicochemical properties and in vitro fermentability by pure cultures of Lactobacillus acidophilus and Bifidobacterium bifidum. Eur Food Res Technol 228, 685-693.

21. Mateos-Aparicio I, Mateos-Peinado C \& Ruperez P (2010) High hydrostatic pressure improves the functionality of dietary fibre in okara by-product from soybean. Innov Food Sci Emerg Technol 11, 445-450

22. Li B, Qiao M \& Lu F (2012) Composition, nutrition, and utilization of Okara (soybean residue). Food Rev Int 28, 231-252.

23. Villanueva MJ, Perez-Cozar ML \& Redondo-Cuenca A (2013) Sequential extraction of polysaccharides from enzymatically hydrolyzed okara byproduct: physicochemical properties and in vitro fermentability. Food Chem 141, 1114-1119.

24. Villanueva MJ, Yokoyama WH, Hong YJ, et al. (2011) Effect of high-fat diets supplemented with okara soybean by-product on lipid profiles of plasma, liver and faeces in Syrian hamsters. Food Chem 124, 72-79.

25. Jimenez-Escrig A, Tenorio MD, Espinosa-Martos I, et al. (2008) Health-promoting effects of a dietary fiber concentrate from the soybean byproduct okara in rats. J Agric Food Chem $\mathbf{5 6}$, 7495-7501.

26. Berardini N, Knodler M, Schieber A, et al. (2005) Utilization of mango peels as a source of pectin and polyphenolics. Innov Food Sci Emerg Technol 6, 442-452.

27. Tu ZC, Chen LL, Wang H, et al. (2014) Effect of fermentation and dynamic high pressure microfluidization on dietary fibre of soybean residue. J Food Sci Technol 51, 3285-3292.

28. Perez-Lopez E, Mateos-Aparicio I \& Ruperez P (2016) Okara treated with high hydrostatic pressure assisted by Ultraflo ${ }^{\circledR} \mathrm{L}$ : effect on solubility of dietary fibre. Innov Food Sci Emerg Technol 33, 32-37.

29. Lambert Y, Demazeau G, Largeteau A, et al. (1999) Changes in aromatic volatile composition of strawberry after high pressure treatment. Food Chem 67, 9.

30. Ferrari G, Maresca P \& Ciccarone R (2010) The application of high hydrostatic pressure for the stabilization of functional foods: pomegranate juice. J Food Eng 100, 245-253.

31. Vervoort L, Van der Plancken I, Grauwet T, et al. (2012) Thermal versus high pressure processing of carrots: a comparative pilot-scale study on equivalent basis. Innov Food Sci Emerg Technol 15, 1-13.

32. Nakamura A, Furuta H, Maeda H, et al. (2001) Analysis of structural components and molecular construction of soybean soluble polysaccharides by stepwise enzymatic degradation. Biosci Biotech Bioch 65, 2249-2258. 
33. Napolitano A, Costabile A, Martin-Pelaiez S, et al. (2009) Potential prebiotic activity of oligosaccharides obtained by enzymatic conversion of durum wheat insoluble dietary fibre into soluble dietary fibre. Nutr Metab Cardiovasc Dis 19, 283-290.

34. Vega-Paulino RJ \& Zuniga-Hansen ME (2012) Potential application of commercial enzyme preparations for industrial production of short-chain fructooligosaccharides. J Mol Catal B-Enzym 76, 44-51.

35. Ruperez P, Perez-Cozar ML, Redondo-Cuenca A, et al. (2011) Método para la obtención de oligosacáridos vegetales. Novel method to prepare vegetable oligosaccharides. Spanish patent application no. 200930375.

36. Kasai $\mathrm{N}$, Murata A, Inui $\mathrm{H}$, et al. (2004) Enzymatic high digestion of soybean milk residue (okara). J Agric Food Chem 52, 5709-5716.

37. AOAC (1995) Method 991.42 \& 993.19. In Official Methods of Analysis, 16th ed. Washington, DC: Association of Official Analytical Chemists.

38. Mañas E \& Saura-Calixto F (1993) Ethanolic precipitation a source of error in dietary fiber determination. Food Chem 47, 351-355.

39. Scott RW (1979) Colorimetric determination of hexuronic acids in plant materials. Anal Chem 51, 936-941.

40. Loewus FA (1952) Improvement in anthrone method for determination of carbohydrates. Anal Chem 24, 219-219.

41. Miller GL (1959) Use of dinitrosalicylic acid reagent for determination of reducing sugar. Anal Chem 31, 426-428.

42. Macfarlane GT, Macfarlane S \& Gibson GR (1998) Validation of a three-stage compound continuous culture system for investigating the effect of retention time on the ecology and metabolism of bacteria in the human colon. Microb Ecol 35, 180-187.

43. Tejero-Sarinena S, Barlow J, Costabile A, et al. (2013) Antipathogenic activity of probiotics against Salmonella typhimurium and Clostridium difficile in anaerobic batch culture systems: Is it due to synergies in probiotic mixtures or the specificity of single strains? Anaerobe 24, 60-65.

44. Franks AH, Harmsen HJM, Raangs GC, et al. (1998) Variations of bacterial populations in human feces measured by fluorescent in situ hybridization with group-specific $16 \mathrm{~S}$ rRNA-targeted oligonucleotide probes. Appl Environ Microbiol 64, 3336-3345.

45. Harmsen HJM, Elfferich P, Schut F, et al. (1999) A 16S rRNAtargeted probe for detection of lactobacilli and enterococci in faecal samples by fluorescent in situ hybridization. Microb Ecol Health Dis 11, 3-12.

46. Walker AW, Duncan SH, McWilliam Leitch EC, et al. (2005) $\mathrm{pH}$ and peptide supply can radically alter bacterial populations and short-chain fatty acid ratios within microbial communities from the human colon. Appl Environ Microbiol 71, 3692-3700.

47. Harmsen HJM, Raangs GC, He T, et al. (2002) Extensive set of $16 \mathrm{~S}$ rRNA-based probes for detection of bacteria in human feces. Appl Environ Microbiol 68, 2982-2990.

48. Manz W, Amann R, Ludwig W, et al. (1996) Application of a suite of 16S rRNA-specific oligonucleotide probes designed to investigate bacteria of the phylum cytophaga-flavobacter-bacteroides in the natural environment. Microbiology 142, 1097-1106.

49. Langendijk PS, Schut F, Jansen GJ, et al. (1995) Quantitative fluorescence in-situ hybridization of bifidobacterium spp with genus-specific $16 \mathrm{~S}$ ribosomal-RNA-targeted probes and its application in fecal samples. Appl Environ Microbiol 61, 3069-3075.

50. Daims H, Bruhl A, Amann R, et al. (1999) The domain-specific probe EUB338 is insufficient for the detection of all bacteria: development and evaluation of a more comprehensive probe set. Syst Appl Microbiol 22, 434-444.

51. Loy A, Horn M \& Wagner M (2003) probeBase: an online resource for rRNA-targeted oligonucleotide probes. Nucleic Acids Res 31, 514-516.

52. Martin-Pelaez S, Gibson GR, Martin-Orue SM, et al. (2008) In vitro fermentation of carbohydrates by porcine faecal inocula and their influence on Salmonella typhimurium growth in batch culture systems. FEMS Microbiol Ecol 66, 608-619.

53. Costabile A, Walton GE, Tzortzis G, et al. (2015) Effects of orange juice formulation on prebiotic functionality using an in vitro colonic model system. PLOS ONE 10, e0121955 [0121912pp.].

54. Henningsson Å, Björck I \& Nyman M (2001) Short-chain fatty acid formation at fermentation of indigestible carbohydrates. J Nutr 132, 3098-3104.

55. Flint HJ, Duncan SH, Scott KP, et al. (2015) Links between diet, gut microbiota composition and gut metabolism. Proc Nutr Soc 74, 13-22.

56. Shahrul RS, Kolida S, Gibson GR, et al. (2013) In vitro fermentation of commercial alpha-gluco-oligosaccharide by faecal microbiota from lean and obese human subjects. $\mathrm{BrJ}$ Nutr 109, 1980-1989.

57. Mateos-Aparicio I, Mateos-Peinado C, Jimenez-Escrig A, et al. (2010) Multifunctional antioxidant activity of polysaccharide fractions from the soybean byproduct okara. Carbohyd Polym 82, 245-250.

58. Duncan SH, Louis P \& Flint HJ (2004) Lactate-utilizing bacteria, isolated from human feces, that produce butyrate as a major fermentation product. Appl Environ Microbiol 70, 5810-5817.

59. Costabile A, Kolida S, Klinder A, et al. (2010) A double-blind, placebo-controlled, cross-over study to establish the bifidogenic effect of a very-long-chain inulin extracted from globe artichoke (Cynara scolymus) in healthy human subjects. Br J Nutr 104, 1007-1017.

60. Lukaczer D, Liska DJ, Lerman RH, et al. (2006) Effect of a low glycemic index diet with soy protein and phytosterols on CVD risk factors in postmenopausal women. Nutrition 22 , 104-113.

61. Jenkins DJA, Kendall CWC, Marchie A, et al. (2003) The effect of combining plant sterols, soy protein, viscous fibers, and almonds in treating hypercholesterolemia. Metabolism 52, 1478-1483.

62. Gibson GR, Probert HM, Van Loo J, et al. (2004) Dietary modulation of the human colonic microbiota: updating the concept of prebiotics. Nutr Res Rev 17, 259-275.

63. Tenorio MD, Espinosa-Martos I, Prestamo G, et al. (2010) Soybean whey enhance mineral balance and caecal fermentation in rats. Eur J Nutr 49, 155-163.

64. Waliszewski KN, Pardio V \& Carreon E (2002) Physicochemical and sensory properties of corn tortillas made from nixtamalized corn flour fortified with spent soymilk residue (okara). J Food Sci 67, 3194-3197. 